University of Nebraska - Lincoln

DigitalCommons@University of Nebraska - Lincoln

Papers in the Earth and Atmospheric Sciences

Earth and Atmospheric Sciences, Department

7-1895

\title{
Lincoln Salt Lake and the Occurrence of Strepsilas interpres
}

\author{
Erwin Hinckley Barbour \\ University of Nebraska-Lincoln
}

Follow this and additional works at: https://digitalcommons.unl.edu/geosciencefacpub

Part of the Earth Sciences Commons

Barbour, Erwin Hinckley, "Lincoln Salt Lake and the Occurrence of Strepsilas interpres" (1895). Papers in the Earth and Atmospheric Sciences. 334.

https://digitalcommons.unl.edu/geosciencefacpub/334

This Article is brought to you for free and open access by the Earth and Atmospheric Sciences, Department of at DigitalCommons@University of Nebraska - Lincoln. It has been accepted for inclusion in Papers in the Earth and Atmospheric Sciences by an authorized administrator of DigitalCommons@University of Nebraska - Lincoln. 
Lincoln Salt Lake and the Occurrence of Strepsilas interpres.- Local ornithologists are considerably interested in the occurrence of the Turnstone (Strepsilas interpres) in this State. Three were shot at Lincoln Salt Lake on the $25^{\text {th }}$ of May of this year. These were secured by .Mr. W. D. Hunter of the Department of Taxidermy, and were placed by him in the State Museum. This is the first authentically reported occurrence of this bird in Nebraska. So far as we can learn it is not reported for any of our neighboring States.

It may be of interest to note that within the last three years the basin of Salt Creek has been artificially dammed, and the water set back so as to form a saline lake about two miles long and one mile wide. Here during the springtime are found great numbers of Gulls, Terns, Ducks, Geese, Waders and Water-birds of all sorts. The Lincoln Gun Club has bought the privileges of this lake, otherwise there would be a continual fusilade kept up against the flocks of birds which hover there. There are but few lakes or marshy places in semi-arid regions to entice Waterbirds, and any one could, by indiscriminate shooting, destroy large numbers of them.

Possibly the salt water of this artificial lake provided food and familiar conditions for these birds which tempted them to linger here in their flight.-ERwin H. Barbour, University of Nebraska, Lincoln, Nebr. 
broken the bone of the toe and nearly severed it from the foot. Mr. Clarke kindly presented me with his rare 'find,' and a photograph, from

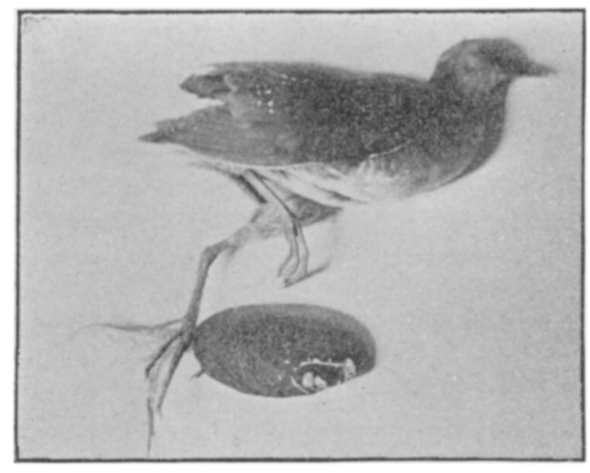

which the accompanying cut was made, was taken at once. The mussel was 2.92 inches long and $\mathrm{I} .6 \mathrm{I}$ wide.-JNo. H. SAGE, Portland, Conn.

An Addition to the Birds of Colorado.-Whilst collecting on June Io, I 895 , in the eastern foothills of the Wet Mountains, Pueblo Co., Colo., at an altitude of 6,000 feet, I had the good fortune to shoot a Scaled Partridge (Callipepla squamata). On mentioning this fact to Prof. W. W. Cooke of Fort Collins, Colo., he informs me that it has not previously been recorded from the State. It is therefore with some pleasure that I am able to add these handsome birds to the list, making the grand total of 348 species recorded from the State.-WilloughBy P. Lowe, Pueblo, Colo.

Additional Records of the Passenger Pigeon in Illinois and Indiana. - The occurrence of the Wild Pigeon (Ectopistes migratorius) in this section of the country, and in fact throughout the west generally, is becoming rarer every year and such observations and data as come to our notice should be of sufficient interest to record.

I have, in the past few months, made inquiry of a great many sportsmen who are constantly in the field and in widely distributed localities, regarding any observations on the Wild Pigeon, and but few of them have seen a specimen in the past eight or ten years. N. W. Judy \& Co. of St. Louis, Mo., dealers in poultry and the largest receivers of game in that section, wrote me as follows: "We have had no Wild Pigeons for two seasons; the last we received were from Siloam Springs, Arkansas. We have lost all track of them and our netters are lying idle."

I have made frequent inquiry among the principal game dealers in Chicago and cannot learn of a single specimen that has been received in our markets in several years. I am indebted to the following gentlemen 